\section{cambridge.org/pao}

\section{Research Article}

Cite this article: Garrett KB, Schott R, Peshock L, Yabsley MJ (2018). Prevalence and diversity of piroplasms and ticks in young raccoons and an association of Babesia sensu stricto infections with splenomegaly. Parasitology Open 4, e12, 1-9. https://doi.org/10.1017/ pao.2018.7

Received: 31 December 2016 Revised: 26 February 2018 Accepted: 28 February 2018

\section{Key words:}

Babesia; infants; neonates; raccoons; splenomegaly; ticks; tick-borne; transmission route; vertical transmission

\section{Author for correspondence:}

Kayla Garrett and Michael Yabsley, E-mail: kaylab92@uga.edu and myabsley@uga.edu (c) Cambridge University Press 2018. This is an Open Access article, distributed under the terms of the Creative Commons AttributionNonCommercial-NoDerivatives licence (http:// creativecommons.org/licenses/by-nc-nd/4.0/), which permits non-commercial re-use, distribution, and reproduction in any medium, provided the original work is unaltered and is properly cited. The written permission of Cambridge University Press must be obtained for commercial re-use or in order to create a derivative work.

\section{CAMBRIDGE UNIVERSITY PRESS}

\title{
Prevalence and diversity of piroplasms and ticks in young raccoons and an association of Babesia sensu stricto infections with splenomegaly
}

Kayla Buck Garrett ${ }^{1,2}$, Renee Schott ${ }^{3}$, Lea Peshock ${ }^{4}$ and Michael J. Yabsley ${ }^{1,2}$

${ }^{1}$ Warnell School of Forestry and Natural Resources, University of Georgia, Athens, GA 30602, USA; ${ }^{2}$ Southeastern Cooperative Wildlife Disease Study, Department of Population Health, College of Veterinary Medicine, University of Georgia, Athens, GA 30602, USA; ${ }^{3}$ Wildlife Rehabilitation Center of Minnesota, 2530 Dale St N, Roseville, MN 55113, USA and ${ }^{4}$ Greenwood Wildlife Rehabilitation Center, 5761 Ute Hwy, Longmont, CO 80503, USA

\begin{abstract}
Piroplasms are intraerythrocytic parasites that are often transmitted by ixodid ticks, but vertical transmission is an alternative route for some species. In the USA, raccoons (Procyon lotor) are hosts for two known species, a Babesia microti-like sp. and Babesia lotori (in Babesia sensu stricto group). To better understand the natural history of Babesia in raccoons, we tested young raccoons from Minnesota and Colorado for Babesia spp., examined them for ticks, and assessing for splenomegaly as a sign of clinical disease. Raccoons from both states were infected with B. microti-like sp. and Babesia sensu stricto spp. Infections of B. microti-like were common, even in 1-week-old raccoons, suggesting vertical transmission. Babesia sensu stricto infections were more common in older raccoons. Raccoons infected with Babesia sensu stricto had significantly higher spleen:body weight ratios compared with uninfected or B. microti-like sp.-infected raccoons. Ticks were only found on raccoons from Minnesota. The most common and abundant tick was Ixodes texanus but Ixodes scapularis and Dermacentor variabilis were also found on raccoons. We report piroplasm infections and infestations with several tick species in very young raccoons. Young raccoons infected with Babesia sensu stricto spp. had higher spleen:body weight ratios, suggesting a disease risk.
\end{abstract}

\section{Introduction}

The piroplasms are an important cause of disease in humans, domestic animals and some wildlife, although most piroplasms in wildlife demonstrate low pathogenicity for their natural host (Hunfeld et al. 2008; Yabsley and Shock, 2012). Most piroplasms with known life cycles use ixodid ticks as vectors (Hunfeld et al. 2008) although vertical transmission has been noted as a possible alternative transmission route for some piroplasms (e.g., Babesia microti in laboratory mice and humans, Babesia gibsoni and Babesia canis canis in dogs and Babesia bovis in cows) (Yeruham et al. 2003; Fukumoto et al. 2005; Joseph et al. 2012; Mierzejewska et al. 2014; Bednarska et al. 2015; Adaszek et al. 2016; Costa et al. 2016). In addition, fighting and intermixing of individuals' blood has been associated with direct transmission of B. gibsoni between fighting dogs (Yeagley et al. 2009).

Babesia infections in raccoons have been reported sporadically throughout the Eastern and Midwestern USA (Schaffer et al. 1978; Anderson et al. 1981; Telford and Forrester, 1991; Birkenheuer et al. 2006, 2007; Clark et al. 2012). However, there are currently little data on the pathogenicity of piroplasm infections in raccoons. A survey of raccoons from Japan with splenomegaly, a pathologic consequence of Babesia infections in other species, found that $8 \%(2 / 24)$ were positive for Babesia spp.; however, only raccoons with splenomegaly were tested (Kawabuchi et al. 2005; Adaszek et al. 2016). Reports of Babesia infections in raccoons are generally based on older studies that utilized blood smears for piroplasms detection (Schaffer et al. 1978; Anderson et al. 1981; Telford and Forrester, 1991).

Two species of morphologically similar, but molecularly distinct, piroplasms have been reported from Florida, Massachusetts, North Carolina and Illinois (Goethert and Telford, 2003; Birkenheuer et al. 2006; Birkenheuer et al. 2007; Clark et al. 2012). One is a species related to B. microti (hereafter called B. microti-like species) and the other is a Babesia sensu stricto species now referred to as B. lotori (also called Babesia sp. AJB-2006) (Anderson et al. 1981; Birkenheuer et al. 2007). The phylogenetic relationships of the piroplasms are under debate, but the $B$. microti clade is considered by many researchers to be a novel genus and likely has many unique biological characteristics (Lack et al. 2012; Schreeg et al. 2016). Without molecular characterization, it is unknown which or both of these species are present in infected raccoons. Furthermore, the prevalence and distribution of these two raccoon piroplasms is poorly known. Outside of the USA, via molecular assays, a low prevalence of B. microti-like parasites and at least one Babesia sensu stricto species have been reported from raccoons introduced to Japan (Kawabuchi et al. 2005; Jinnai et al. 2009). 
Currently, the transmission route is unknown for both Babesia spp. of raccoons but it is presumed to be via ixodid ticks as most piroplasms are transmitted by ixodid ticks (Uilenberg, 2006; Hunfeld et al. 2008). Raccoons are commonly infested with several tick species including Ixodes texanus, Ixodes cookei, Ixodes scapularis, Ixodes affinis, Dermacentor variabilis, Amblyomma americanum and $A$. maculatum, but the geographic distribution and seasonality of many of these tick species varies (Dennis et al. 1994; Ouellette et al. 1997; Yabsley et al. 2008). In North Carolina, both piroplasms are found in raccoons in high prevalences (Birkenheuer et al. 2006), so the vector, if there is one, is presumed to be a common tick species found on raccoons. Unfortunately, all of the tick species noted above are found in North Carolina so testing of raccoons from various parts of North America would be needed to better identify possible tick vectors (Ouellette et al. 1997; Birkenheuer et al. 2006). However, there is the possibility of alternative transmission routes.

Numerous questions remain regarding the natural history of piroplasm infections in raccoons, including the prevalence and diversity of different piroplasm species infecting raccoons, modes of transmission and pathogenicity. Thus, our objectives were to determine the prevalence of Babesia in young raccoons under the age of 6 weeks old and, if they occurred, what species of Babesia were present. We hypothesized that young raccoons would be infected with at least the two species of piroplasms previously reported in raccoons as the prevalence of both are very high in adult raccoons. In addition, we calculated a spleen:body weight ratio to determine if raccoons infected with Babesia spp. had larger spleens because splenomegaly has been associated with piroplasm infections. Finally, we examined the raccoons to determine if an infestation of ticks occurred while still in the nest, as raccoons younger than 6 weeks old typically do not venture from the nest (Schneider et al. 1971; Gehrt and Fritzell, 1998). The current vector(s) of any piroplasms of raccoons are unknown but if piroplasm infections were noted in young raccoons, I. texanus, a tick species that is transmitted among raccoons in the nest (Anderson et al. 1981), would be expected to be present and would possibly be associated with transmission. However, it is also possible that other tick species may be transmitted to young raccoons within the nest environment. We sampled young raccoons in Minnesota and Colorado where we have previously detected Babesia infections in adult raccoons (Garrett and Yabsley, unpublished data).

\section{Methods}

\section{Sample collection}

From April to November of 2016, samples were collected from fetal, neonatal or juvenile raccoons admitted to two rehabilitation facilities: the Wildlife Rehabilitation Center of Minnesota (Roseville, MN) and the Greenwood Wildlife Rehabilitation Center in Colorado (Longmont, CO). The raccoons sampled were presented to the centres deceased, died while in care, or were euthanized due to poor prognosis. Raccoons were frozen immediately after death to ensure no decomposition occurred and shipped to the Southeastern Cooperative Wildlife Disease Study (Athens, GA) where they were processed. Raccoons were examined for ectoparasites, which if found, were preserved in $70 \%$ ethanol until identification. Ticks were identified morphologically using published keys (Keirans and Litwak, 1989; Durden and Keirans, 1996; Guglielmone et al. 2014) or by using molecular methods as described below. Spleens were removed after examination, weighed and re-frozen at $-20^{\circ} \mathrm{C}$ until testing.

Data collected from each raccoon included weight, body length, sex and estimated age based on tooth eruption
(Montgomery, 1964). For a limited number of raccoons, age was approximated based on weight because of missing or damaged teeth. The age of remaining raccoons was also estimated based on weight and both methods provided similar results (data not shown). Although no animals were euthanized for the purposes of this study, the collection of biological samples for pathogen testing was reviewed and approved by UGA's Institutional Animal Care and Use Committee (A2014 10-018).

\section{Molecular testing}

Genomic DNA was extracted from $\sim 10 \mathrm{mg}$ of spleen using a commercial kit per the manufacturer's instructions (DNEasy Blood and Tissue kit, Qiagen, Hilden, Germany). Two different PCR (polymerase chain reaction) assays targeting the V4 region of the 18S rRNA gene of Babesia were used as described (Birkenheuer et al. 2003, 2007). One set of primers, BMlikeF (5'-CTGCCTTATCATTAATTTCGCTTCCGAACG) and 793772R (5'-ATGCCCCCAACCGTTCCTATTA), targets Babesia parasites in the B. microti-like clade. Molecular analyses were conducted on a BioRad DNA Engine Peltier Thermal Cycler (Bio-Rad Laboratories Incorporated, Foster City, CA). Cycling parameters were $94^{\circ} \mathrm{C}$ for 5 min followed by 49 cycles of $94^{\circ} \mathrm{C}$ for $45 \mathrm{~s}, 56^{\circ} \mathrm{C}$ for $45 \mathrm{~s}$ and $72{ }^{\circ} \mathrm{C}$ for $45 \mathrm{~s}$, with a final extension of $72{ }^{\circ} \mathrm{C}$ for $5 \mathrm{~min}$. The other set of primers, $455-479 \mathrm{~F}$ (5'-GTCTTGTAATTGG-AATGATGGTGAC) and 793-772R, were used to detect Babesia sensu stricto species. Cycling parameters were $94{ }^{\circ} \mathrm{C}$ for $3 \mathrm{~min}$ followed by 44 cycles of $94{ }^{\circ} \mathrm{C}$ for $30 \mathrm{~s}, 60^{\circ} \mathrm{C}$ for $30 \mathrm{~s}, 72{ }^{\circ} \mathrm{C}$ for $30 \mathrm{~s}$, with a final extension of $72{ }^{\circ} \mathrm{C}$ for $5 \mathrm{~min}$.

Precautions were taken to prevent and detect contamination including the performance of DNA extraction, PCR reaction setup, and product analysis in distinct, designated areas. Negative water controls were included in each set of DNA extractions. For each batch of PCR reactions, the extraction negative control, a new water negative control and a positive control (DNA sample from a pooled blood sample with the sequencedconfirmed presence of $B$. lotori and B. microti-like sp.) were included. Amplicons were observed in a GelRed stained 1.5\% agarose gel. Gels were run for an extended period of time to ensure the reliable distinction between amplicon sizes.

Because the screening PCR assays amplify a small amplicon not ideal for species identification, especially within the Babesia sensu stricto group, 11 samples positive with the Babesia sensu stricto group $18 \mathrm{~S}$ screening primer set were also tested using a PCR targeting the cytochrome $c$ oxidase subunit $1(\operatorname{cox} 1)$ region and products were sequenced to identify species present. Primers Babcox1F (5'-GGAAGTGGWACWGG-WTGGAC) and Babcox1R (5'-TTC GGTATTGCATGCCTTG) were used and cycling parameters were $95^{\circ} \mathrm{C}$ for $5 \mathrm{~min}$ followed by 45 cycles of $95^{\circ} \mathrm{C}$ for $20 \mathrm{~s}$, $50{ }^{\circ} \mathrm{C}$ for $30 \mathrm{~s}, 68^{\circ} \mathrm{C}$ for $1 \mathrm{~min}$ and $30 \mathrm{~s}$, and a final extension of $72^{\circ} \mathrm{C}$ for $5 \mathrm{~min}$ (Schreeg et al. 2016). For eight samples that were coinfected and a Babesia sensu stricto sequence was not obtained using the $18 \mathrm{~S}$ screening or cox 1 gene protocols, we conducted an additional PCR using Babesia sensu stricto-specific primers that target two regions of the large subunit rRNA (LSU) gene fragment (lsu5 and lsu4) (Qurollo et al. 2017).

To confirm the presence of $B$. microti-like sp. in a subset of samples the BMlikeF/793-772R amplicon was sequenced (nine samples) or a larger region of the 18S rRNA gene was amplified with primers $522 \mathrm{~F}$ and $1661 \mathrm{R}$ and sequenced (four samples) (Birkenheuer et al. 2007).

Amplicons were purified from an agarose gel using a gelpurification kit (Qiagen) and bi-directionally sequenced at the University of Georgia Genomics Facility (Athens, GA). Sequences were cleaned using the Geneious program (Biomatters Limited, 
Auckland New, Zealand) and consensus sequences compared with other Babesia sequences in GenBank.

Some Ixodes ticks were damaged during removal and could not be identified to species using morphologic characteristics. Tick DNA was extracted and amplified as described (Gleim et al. 2014). Primers $16 \mathrm{~S}-1$ (5'-CCGGTCTGAACTCAGAT CAAGT) and 16S + 2 (5'-TTGGGCAAGAAGACCCTATGAA) targeting the $16 \mathrm{~S}$ rRNA gene were used and cycling parameters were $94{ }^{\circ} \mathrm{C}$ for $2 \mathrm{~min}$ followed by 40 cycles of $94^{\circ} \mathrm{C}$ for $30 \mathrm{~s}$, $45^{\circ} \mathrm{C}$ for $30 \mathrm{~s}, 72{ }^{\circ} \mathrm{C}$ for $1 \mathrm{~min}$ and a final extension of $72{ }^{\circ} \mathrm{C}$ for $5 \mathrm{~min}$. Amplicons were sequenced as described above.

\section{Statistical analyses}

A Fisher's exact test was used to compare the prevalence of the B. microti-like sp. and Babesia sensu stricto. In order to determine the relationships between parasite prevalence and the different variables, a generalized linear model (GLM) was utilized and the data log transformed. The variables measured included sex, age (by week), spleen:body weight ratio and whether or not ticks were present. A separate GLM was performed for the B. microti-like sp. and Babesia sensu stricto datasets.

\section{Results}

A total of 106 young raccoons from Minnesota $(n=83)$ and Colorado $(n=23)$ were included in the study and $66 \%(70 / 106)$ were infected with Babesia. The prevalence of $B$. microti-like sp. [66/106 (62\%)] was significantly higher than that of Babesia sensu stricto $[11 / 106(10 \%)(P=0.0001)]$. A total of eight (7.5\%) raccoons had coinfections. For the B. microti-like sp., infections were detected in individuals as young as 1 week of age and prevalence was high in all age groups (Table 1). For the Babesia sensu stricto group, infections were first noted at 2 weeks of age but prevalence was low, while prevalence in raccoons that were 6 weeks or older was $40 \%$ (Table 1). Table 2 shows the data for the 59 raccoons from Minnesota that were admitted in identifiable litters. In general, the prevalence of Babesia within litters was high but for most litters, not all individuals were infected (Table 2).

Eight of the 11 Babesia sensu stricto samples amplified with the cox1 PCR protocol but only five provided good quality sequences (all from Minnesota). One sequence was most similar (99.8\%) to a Babesia sp. reported from a captive maned wolf (Chrysocyon brachyurus) (KR017881) but was also 98.3\% similar to Babesia lotori (accessioned as Babesia sp. AJB-2006, KR017882) of raccoons. Two other sequences, from the same litter of raccoons, were identical to each other and, although they were most similar to B. lotori, they only shared $84.2 \%$ similarity (Table 2 ). The remaining two sequences were most similar $(90.4 \%)$ to $B$. vulpes (a B. microti-like sp. of fox and dogs, accessed in GenBank as Babesia sp. MES-2012, KC207827); however, these sequences were identical to unpublished sequences of the B. microti-like sp. of raccoons (Garrett and Yabsley, unpublished data). Both of these raccoons were coinfected with a Babesia sensu stricto based on the screening 18S PCR; one (16-5935) of which had a partial $18 \mathrm{~S}$ sequence to confirm Babesia sensu stricto infection (Table 3). All eight of the raccoons that were coinfected samples were successfully amplified using the LSU rRNA gene PCR assay. These LSU sequences were (97.3-99.7\%) similar to Babesia lintan (Table 3). However, based on sequences from the cox1, 18S rRNA and LSU gene sequences, there were three distinct groups of Babesia sensu stricto (Table 3). Unique cox1 and 18S rRNA gene sequences were submitted to GenBank (accession numbers MG986879-MG986888).

Many of the samples positive for the B. microti-like sp. using the screen PCR did not produce amplicons with the cox1 PCR protocol, so to confirm infections with this species, we sequenced amplicons from the two different $18 \mathrm{~S}$ PCR protocols. Near fulllength $18 \mathrm{~S}$ rRNA sequences were acquired for four raccoons and shorter 18S rRNA sequences were obtained for six additional raccoons, including the three raccoons in the 1-week-old litter (Table 2). All of these sequences were identical or most similar $(>99.5 \%)$ to the $B$. microti-like sp. sequences from raccoons available in GenBank (AB197940, AB935335 and AY144701).

Three tick species were found on young raccoons including I. texanus, I. scapularis and D. variabilis, all from raccoons from Minnesota (Table 4). Damaged ticks that could not be identified to species based on morphological characteristics were identified as I. texanus using PCR and sequence analysis. All life stages of $I$. texanus were detected while only larvae and nymphs of $I$. scapularis were found. Infestation with I. texanus was first noted on raccoons at 2 weeks of age and the infestation prevalence was similar for all age groups (Fig. 1A). In contrast, I. scapularis

Table 1. Prevalence of Babesia spp. in young raccoons from Colorado and Minnesota, by age class ${ }^{a}$

\begin{tabular}{|c|c|c|c|c|c|c|c|c|c|}
\hline \multirow[b]{2}{*}{ State } & \multirow[b]{2}{*}{ Parasite } & \multicolumn{8}{|c|}{ Age in weeks no. positive/no. tested (\% positive) } \\
\hline & & $<1^{b}$ & 1 & 2 & 3 & 4 & 5 & $6+$ & Total \\
\hline \multirow[t]{3}{*}{ Minnesota } & $\begin{array}{l}\text { Babesia } \\
\text { microti-like sp. }\end{array}$ & $0 / 3$ & $3 / 3(100)$ & $9 / 19(47)$ & $13 / 25(52)$ & $13 / 18(72)$ & $3 / 5(60)$ & $9 / 10(90)$ & $50 / 83(60)$ \\
\hline & $\begin{array}{l}\text { Babesia sensu } \\
\text { stricto group }\end{array}$ & $0 / 3$ & $0 / 3$ & $0 / 19$ & $3 / 25(12)$ & $1 / 18(6)$ & $1 / 5(20)$ & $3 / 10(30)$ & $8 / 83(10)$ \\
\hline & Coinfected & $0 / 3$ & $0 / 3$ & $0 / 19$ & $2 / 25(8)$ & $0 / 18$ & $0 / 5$ & $3 / 10(30)$ & $5 / 83(6)$ \\
\hline \multirow[t]{3}{*}{ Colorado } & B. microti-like sp. & NT & $3 / 3(100)$ & $1 / 3(33)$ & $1 / 3(33)$ & NT & $3 / 3(100)$ & $4 / 5(80)$ & $12 / 17(70)$ \\
\hline & $\begin{array}{l}\text { Babesia sensu } \\
\text { stricto group }\end{array}$ & NT & $0 / 3$ & $1 / 3(33)$ & $0 / 3$ & NT & $0 / 3$ & $2 / 5(40)$ & $3 / 17(18)$ \\
\hline & Coinfected & NT & $0 / 3$ & $1 / 3(33)$ & $0 / 3$ & NT & $0 / 3$ & $2 / 5(40)$ & $3 / 17(18)$ \\
\hline \multirow[t]{3}{*}{ Total } & B. microti-like sp. & $0 / 3$ & $6 / 6(100)$ & $10 / 22(45)$ & $14 / 28(50)$ & $13 / 18(72)$ & $6 / 8(75)$ & $13 / 15(87)$ & $62 / 100(62)$ \\
\hline & $\begin{array}{l}\text { Babesia sensu } \\
\text { stricto group }\end{array}$ & $0 / 3$ & $0 / 3$ & $1 / 22(5)$ & $3 / 28(11)$ & $1 / 18(6)$ & $1 / 8(13)$ & $5 / 15(33)$ & $11 / 100(11)$ \\
\hline & Coinfected & $0 / 3$ & $0 / 3$ & $1 / 22(5)$ & $2 / 28(7)$ & $0 / 18$ & $0 / 8$ & $5 / 15(33)$ & $8 / 100(8)$ \\
\hline
\end{tabular}

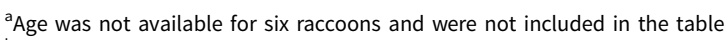

${ }^{\mathrm{b}}$ These three raccoons were near-term and removed via caesarian section from a deceased female. 
Table 2. Data on Babesia infections and ticks on raccoons from identifiable litters from Minnesota.

\begin{tabular}{|c|c|c|c|c|c|c|}
\hline \multirow[b]{2}{*}{ Litter } & \multirow[b]{2}{*}{$\begin{array}{l}\text { Estimated age } \\
\text { (weeks) }\end{array}$} & \multirow[b]{2}{*}{$\begin{array}{l}\text { No. of kits } \\
\text { admitted }\end{array}$} & \multirow[b]{2}{*}{$\begin{array}{l}\text { No. of kits } \\
\text { infested with ticks }\end{array}$} & \multicolumn{2}{|c|}{ No. of infected } & \multirow{2}{*}{$\begin{array}{l}\text { Species present based } \\
\text { on sequence analysis } \\
\text { (gene target) }\end{array}$} \\
\hline & & & & B. microti-like sp. & $\begin{array}{l}\text { Babesia sensu } \\
\text { stricto sp. }\end{array}$ & \\
\hline 1 & Fetal & 3 & 0 & 0 & 0 & ND \\
\hline 2 & 1.5 & 5 & $5(\mathrm{IT})$ & 3 & 0 & $\begin{array}{l}\text { Three with } B \text {. microti-like } \\
\text { sp. (18S rRNA) }\end{array}$ \\
\hline 3 & $1.5-2.5$ & 4 & 0 & 2 & 0 & ND \\
\hline 4 & 1 & 3 & 0 & 3 & 0 & $\begin{array}{l}\text { Three B. microti-like sp. } \\
\text { (18S rRNA) }\end{array}$ \\
\hline 5 & 2 & 5 & 0 & 2 & 0 & ND \\
\hline 6 & 1.5 & 2 & $2(\mathrm{IT})$ & 1 & 0 & ND \\
\hline 7 & $2.5-3$ & 5 & 1 (DV) & 4 & 0 & ND \\
\hline 8 & 4 & 3 & $2(\mathrm{IT})$ & 3 & 0 & ND \\
\hline 9 & 2 & 3 & $1(\mathrm{DV}, \mathrm{IT})$ & 1 & 0 & $\begin{array}{l}\text { B. microti-like sp. (18S } \\
\text { rRNA) }\end{array}$ \\
\hline 10 & 2.5 & 4 & $2(\mathrm{IT})$ & 1 & 2 & $\begin{array}{l}\text { Both confirmed Babesia } \\
\text { sensu stricto sp. (18S rRNA } \\
\text { and LSU) })^{\text {a }} \text { One with } B \text {. } \\
\text { microti-like sp. (cox1) }\end{array}$ \\
\hline 11 & $4-5$ & 2 & 0 & 2 & 2 & $\begin{array}{l}\text { Both with } B \text {. microti-like sp. } \\
\text { (18S rRNA); Both with } \\
\text { Babesia sensu stricto (LSU) }\end{array}$ \\
\hline 12 & $4-5$ & 2 & 0 & 2 & 0 & $\begin{array}{l}\text { One with } B . \text { microti-like sp. } \\
\text { (18S rRNA) }\end{array}$ \\
\hline 13 & 3 & 2 & 0 & 0 & 0 & ND \\
\hline 14 & 3 & 3 & $3(\mathrm{DV}, \mathrm{IT})$ & 1 & 0 & ND \\
\hline 15 & 3 & 3 & 1 (IT) & 1 & 0 & ND \\
\hline 16 & $4-5.5$ & 3 & 3 (IT) & 2 & 0 & ND \\
\hline 17 & $3-4$ & 3 & 1 (IT) & 3 & 0 & ND \\
\hline 18 & $3-4$ & 4 & $4(\mathrm{DV}, \mathrm{IT})$ & 3 & 1 & ND \\
\hline
\end{tabular}

IT, Ixodes texanus; DV, Dermacentor variabilis; Cox1, cytochrome c oxidase subunit I; LSU, large subunit rRNA; ND, not done.

aaccoons $16-4482$ and $16-4484$ in Table 3.

${ }^{\mathrm{b}}$ Raccoons $16-4596$ and $16-4597$ in Table 3.

infestations were primarily noted in raccoons older than 5 weeks of age, although a single 3-week-old raccoon was infested with two I. scapularis nymphs (Fig. 1A). Infestation prevalence for D. variabilis increased with age (Fig. 1A). The mean number of I. texanus collected from infested raccoons was highest for raccoons in the 2-week age group with two individuals having 54 and 64 ticks, respectively (Fig. 1B). Other than those two raccoons with high $I$. texanus infestations, tick burdens were generally low with a maximum number of ticks collected from an individual being three $I$. scapularis and $13 \mathrm{D}$. variabilis. Most ticks were found in the ears or on the face (Fig. 2) although two raccoons had ticks present on multiple parts of the body. Presence of ticks was not a significant predictor variable for infection with either piroplasm (B. microti-like sp.: $P=0.2393$; Babesia sensu stricto: $P=0.3604)$.

Using GLM, the only significant variable for raccoons infected with $B$. microti-like sp. was age $(P=0.0059)$. According to the GLM, infection of raccoons with Babesia sensu stricto was associated with age $(P=0.0017)$ and spleen:body weight ratio $(P=$ 0.0005). Also, raccoons with Babesia sensu stricto infections had significantly higher spleen:body weight ratios compared with raccoons infected with $B$. microti-like sp. only or those with no Babesia infection $(P=0.0008$ and $P<0.0001$, respectively)
(Fig. 3). Although not significantly different from either group, coinfected raccoons had increased average spleen:body ratio $(P=0.374)$ (Fig. 3).

\section{Discussion}

We detected Babesia infections in young raccoons from Minnesota and Colorado with the B. microti-like sp. detected in individuals as young as 1 week of age. There was a high prevalence of the B. microti-like sp. in raccoons from Minnesota and Colorado, and although Babesia sensu stricto infections were detected, the prevalence was much lower. We obtained sequence confirmation for the two piroplasms previously reported from raccoons (a $B$. microti-like sp. and B. lotori), but we also found possible novel Babesia spp. (groups B and C in Table 3). We also noted coinfections occurring in some young raccoons; however, the prevalence of coinfection in both states was much lower than previously reported for adult raccoons in North Carolina, but this is likely due to the lower prevalence of Babesia sensu stricto infections among the young raccoons we tested (Birkenheuer et al. 2006). These data extend the known range of B. lotori to Minnesota and confirms that Babesia sensu stricto 


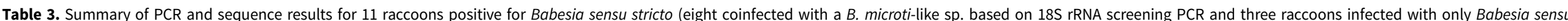
stricto)

\begin{tabular}{|c|c|c|c|c|c|c|}
\hline Group & ID & $\begin{array}{l}\text { Babesia sensu } \\
\text { stricto group }^{a}\end{array}$ & $\begin{array}{l}\text { Cytochrome c oxidase } \\
\text { subunit } 1\end{array}$ & $18 \mathrm{~S}$ rRNA gene (long segment) & $\begin{array}{l}\text { 18S rRNA gene (short } \\
\text { segment, screening protocol) }\end{array}$ & Large subunit rRNA gene \\
\hline \multirow[t]{8}{*}{ Neonates - coinfected } & $16-4596$ & A & n.a. ${ }^{b}$ & $\begin{array}{l}99.4 \%(1013 / 1019) \text { to Babesia sp. from } \\
\text { raccoon (AB197940) - a B. microti-like } \\
\text { sp. }\end{array}$ & $\begin{array}{l}99.1 \%(337 / 340) \text { to Babesia sp. } \\
\text { from Japan (AB935172, AB251608) }\end{array}$ & $98.1 \%(151 / 154)$ to B. lintan (KX698109) \\
\hline & $16-4597$ & A & n.a. & $\begin{array}{l}99.4 \%(478 / 481) \text { to Babesia sp. from } \\
\text { raccoons (AB197940, AY144701, } \\
\text { AB935335) - a B. microti-like sp. }\end{array}$ & $\begin{array}{l}99.4 \%(326 / 328) \text { to Babesia sp. } \\
\text { from Japan (AB935172, AB251608) }\end{array}$ & $98.1 \%(151 / 154)$ to $B$. lintan (KX698109) \\
\hline & $16-5713$ & B & $\begin{array}{l}99.8 \%(863 / 865) \text { to a } \\
\text { Babesia sp. from a maned } \\
\text { wolf (KR017881) }\end{array}$ & $\mathrm{n} / \mathrm{d}^{\mathrm{c}}$ & n.a. & $99.4 \%(153 / 154)$ to $B$. lintan (KX698109) \\
\hline & $16-5935$ & B & $\begin{array}{l}90.4 \%[903 / 999] \text { to } B . \text { vulpes } \\
\text { (KC207827) - a B. } \\
\text { microti-like sp. }\end{array}$ & $\begin{array}{l}99.5 \%(551 / 554) \text { to Babesia sp. from } \\
\text { raccoons (AB197940, AY144701, } \\
\text { AB935335) - a B. microti-like sp. }\end{array}$ & $\begin{array}{l}98.8 \%(327 / 331) \text { to a Babesia sp. } \\
\text { from a maned wolf (KR017880) }\end{array}$ & $99.7 \%(152 / 154)$ to $B$. lintan (KX698109) \\
\hline & $16-5159$ & c & $\begin{array}{l}90.4 \%[856 / 949] \text { to } B . \text { vulpes } \\
\text { (KC207827) - a B. } \\
\text { microti-like sp. }\end{array}$ & $\begin{array}{l}98.7 \%(466 / 472) \text { to Babesia sp. from } \\
\text { raccoons (AB197940, AY144701) - a B. } \\
\text { microti-like sp. }\end{array}$ & n.a. & $97.3 \%(107 / 110)$ to $B$. lintan (KX698109) \\
\hline & CO-498 & B & n.a. & $\mathrm{n} / \mathrm{d}$ & n.a. & $99.4 \%(153 / 154)$ to B. lintan (KX698109) \\
\hline & CO-1350 & B & n.a. & $\mathrm{n} / \mathrm{d}$ & n.a. & $99.4 \%(153 / 154)$ to $B$. lintan (KX698109) \\
\hline & CO-861 & B & n.a. & $n / d$ & n.a. & $99.3 \%(151 / 152)$ to $B$. lintan (KX698109) \\
\hline \multirow{3}{*}{$\begin{array}{l}\text { Neonates - only } \\
\text { infected with Babesia } \\
\text { sensu stricto }\end{array}$} & $16-4484$ & A & $\begin{array}{l}84.2 \%(758 / 900) \text { to } B . \text { lotori } \\
\text { (KR017882) }\end{array}$ & $\mathrm{n} / \mathrm{d}$ & n.a. & $98.1 \%(151 / 154)$ to $B$. lintan (KX698109) \\
\hline & $16-5938$ & A & $\mathrm{n} / \mathrm{a}$ & $n / d$ & $\begin{array}{l}99.1 \%(338 / 341) \text { to Babesia sp. } \\
\text { from Japan (AB935172, AB251608) }\end{array}$ & $n / d$ \\
\hline & $16-4482$ & A & $\begin{array}{l}84.2 \%(758 / 900) \text { to } B . \text { lotori } \\
\text { (KR017882) }\end{array}$ & $n / d$ & $\begin{array}{l}99.4 \%(326 / 328) \text { to Babesia sp. } \\
\text { from Japan (AB935172, AB251608) }\end{array}$ & $\mathrm{n} / \mathrm{a}$ \\
\hline
\end{tabular}

Three groups of Babesia sensu stricto were identified based on sequences of the three gene targets.

${ }^{b}$ n.a., not available (PCR either was negative or we were unable to get a clean sequence).

$c_{n} / d$, not done. 
Table 4. Number and stage of ticks collected from young raccoons from Minnesota

\begin{tabular}{lrrrrr}
\hline & & & Tick stage \\
\cline { 3 - 5 } Tick species & \multicolumn{1}{c}{$n$} & Larvae & Nymph & Male \\
\hline Ixodes texanus & 211 & 7 & 133 & 6 & 0 \\
\hline Ixodes scapularis & 9 & 3 & 1 & 0 \\
\hline Dermacentor variabilis & 49 & 0 & 30 \\
\hline
\end{tabular}
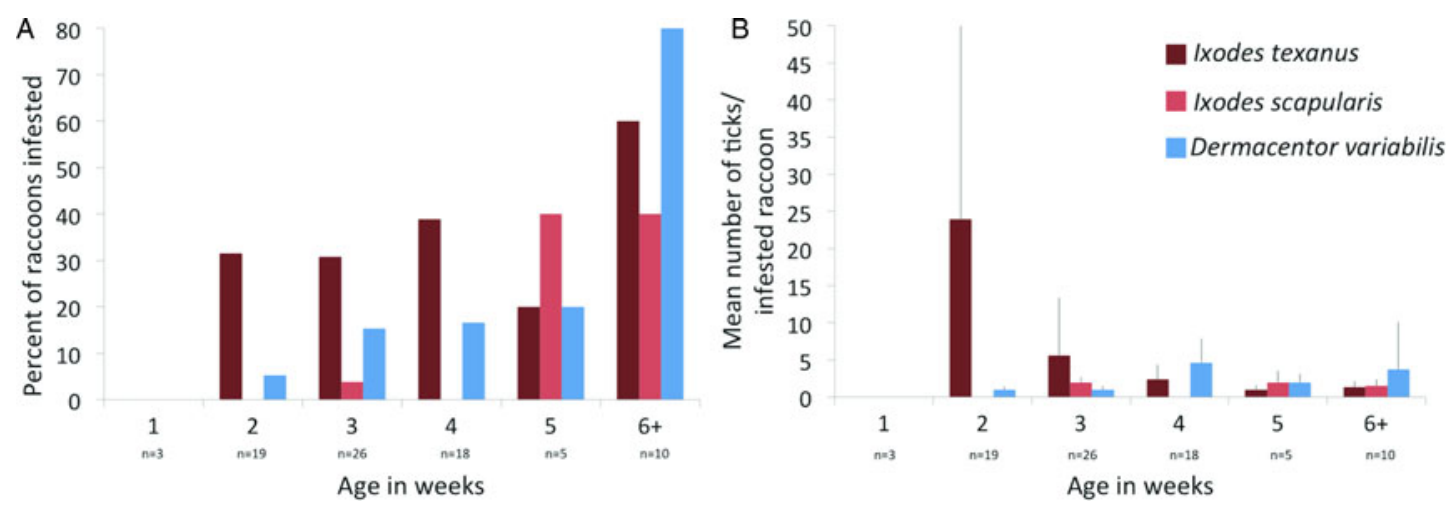

Fig. 1. (A) Per cent of young raccoon infested with ticks by age class in weeks (number of raccoons sampled in each age class show below age). (B) Average number of ticks from infested raccoons in each age class in weeks. Number of raccoons sampled is the same as in (A).

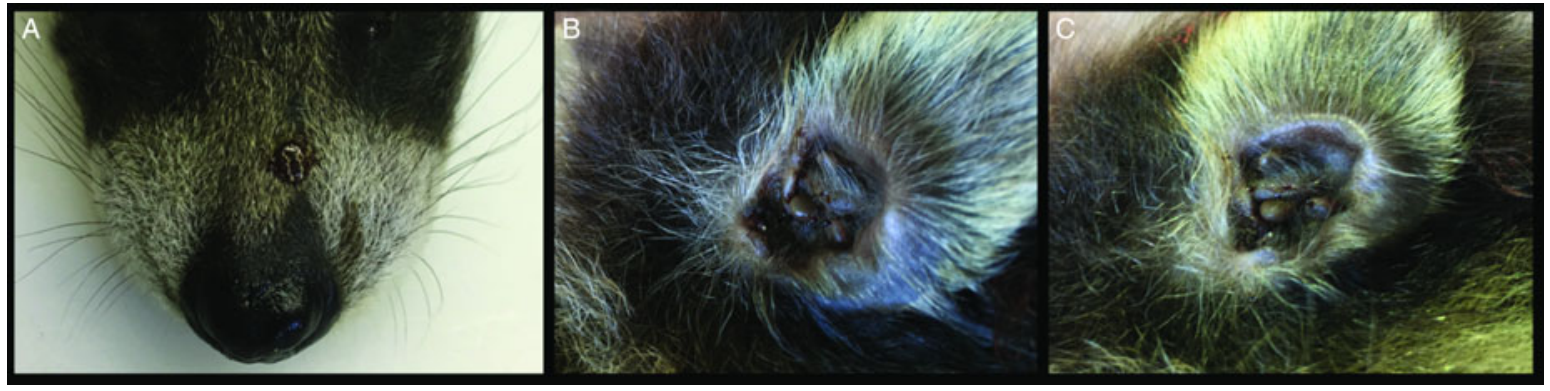

Fig. 2. Ticks on a 1.5-week-old raccoon. (A) An adult Dermacentor variabilis on snout. (B) Several nymphal and adult Ixodes texanus in an ear. (C) Several adult $I$. texanus in an ear.

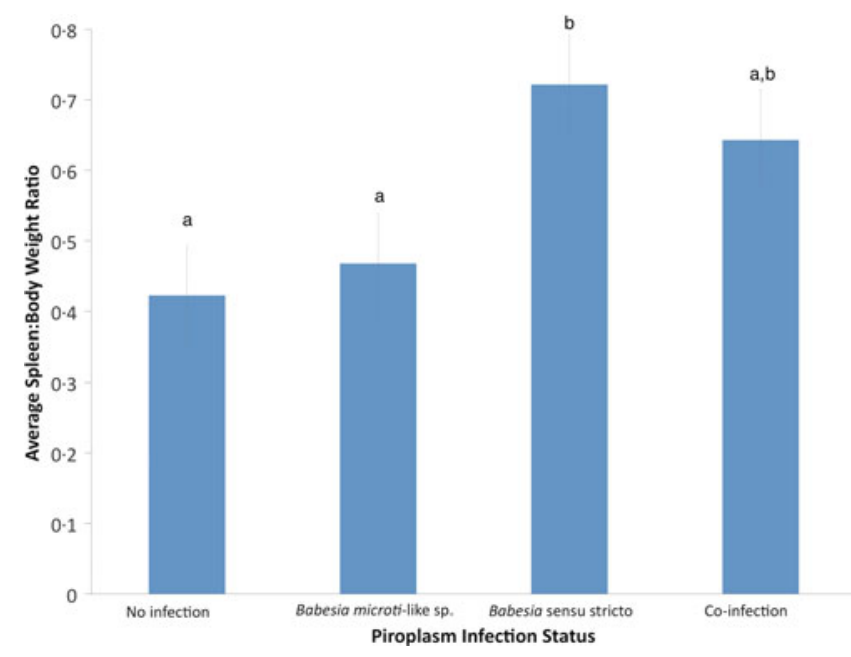

Fig. 3. Effects of Babesia infection on average spleen:body weight ratio of young raccoons with standard error bars. Different letters denote significant differences among groups. spp. occur in Minnesota and the B. microti-like sp. occurs in Minnesota and Colorado.

The only previous study to investigate Babesia infections in young racccons was conducted in Connecticut and our data support those findings (Anderson et al. 1981). Anderson et al. (1981) found that three of four young raccoons were positive for Babesia and nymphal $I$. texanus ticks were found on two of the raccoons. However, in the previous study, infections in raccoons were determined based on blood smear analysis and thus the species of Babesia present was unknown and the age of the raccoons was not specified. Generally, we found a high prevalence of Babesia among identifiable litters and although not all individuals in a litter were infected, these data were similar to data on vertical transmission of B. microti in voles (Tolkacz et al. 2017).

A primary goal of our study was to determine if young raccoons were infected with Babesia and investigate the possible role of vertical transmission as a route of infection. However, because we also detected a high prevalence of tick infestation on raccoons from Minnesota, it is unknown if the infections in young raccoons were acquired vertically from infected female 
raccoons or were due to infestation with ticks at a very young age. While we did not find ticks on raccoons younger than 2 weeks of age, our sample size for 1-week-old raccoons was limited so it is possible that raccoons become infested with ticks earlier than we noted. We also did not note any infection in the three fetal raccoons; however, this was also a small sample size and samples from the dam were not available for analysis.

The prepatent period is generally unknown for many piroplasms and varies by transmission route and detection method, so reported data may not be valid for raccoon-infecting piroplasms. For vertical transmission of B. microti, voles in Europe had a 3-week prepatent period and experimentally infected $\mathrm{BALB} / \mathrm{c}$ laboratory mice had a 20-day prepatent period (Bednarska et al. 2015; Tolkacz et al. 2017). Our data suggest that some Babesia infections may be acquired due to vertical transmission, as we detected $B$. microti-like sp. infections in raccoons as young as 1 week old which is generally shorter than prepatent periods associated with tick transmission (e.g., 13-28 days for B. microti to rhesus macaques (Macaca mulatta) and 13-17 days to BALB/c mice) (Ruebush et al. 1981; Li et al. 2016).

For Babesia sensu stricto spp., short prepatent periods after exposure of hosts to infected ticks have been documented. The prepatent period for B. canis transmitted to dogs by Rhipicephalus sanguineus was 6 days post-infection, whereas cattle became infected with Babesia major within 9-15 days after exposure to infected Haemaphysalis punctate (Paraense, 1949; Yin et al. 1996). Vertical transmission of Babesia sensu stricto sp. has also been noted with beagle puppies, whose mother was intravenously inoculated with $B$. gibsoni prior to mating, showing infection after 14 days (Fukumoto et al. 2005). Other cases of vertical transmission of Babesia sensu stricto sp. have been reported in puppies infected with Babesia canis 6 weeks after birth and in puppies with clinical signs after 8 weeks from presumed vertical transmission of $B$. canis canis (Mierzejewska et al. 2014; Adaszek et al. 2016). Because infections of raccoons with Babesia sensu stricto were not noted until at least 2-3 weeks of age, which is within the time frame of tick-transmitted prepatent periods, it is possible that these two groups of Babesia, B. microti-like sp. and Babesia sensu stricto sp., utilize different transmission strategies.

Ticks, specifically ixodid ticks, are the presumed vectors for Babesia sp. and are important to discuss when considering the lifecycle of these raccoon piroplasms (Hunfeld et al. 2008). The tick species found on our young raccoons from Minnesota are commonly reported on raccoons (Dennis et al. 1994; Ouellette et al. 1997; Hersh et al. 2012). Ixodes texanus was the most common and abundant tick found on the raccoons which was expected as this species is found on host's year-around and is assumed to be acquired within the nests of their vertebrate hosts (Sonenshine, 1993; Dharmarajan et al. 2016). This tick species has a widespread distribution in the USA (Eastern and Midwestern USA, California, and Alaska and likely many states in between) (Ouellette et al. 1997; Gabriel et al. 2009; Durden et al. 2016). The other two species found on our raccoons included D. variablis (restricted to the Eastern USA and in isolated populations in California) and I. scapularis (restricted to the Eastern USA) (Bishopp and Trembley, 1945). Larval and nymphal stages of $I$. scapularis feed on a wide range of small to medium-sized hosts (mammals, birds, lizards), including raccoons, and this species is an important vector of Borrelia burgdorferi, the causative agent of Lyme disease, and B. microti, the primary causative agent of human babesiosis in the USA (Hersh et al. 2012). In our study, only larvae and nymphs of $I$. scapularis were found on raccoons and in very low numbers, most likely because of the earlier seasonal activity of these stages compared with adults, which are more often found on hosts in fall and winter (Bishopp and Trembley, 1945). Raccoons younger than 6-8 weeks most likely acquire ticks from the mother, as young of this age do not typically venture from the nest, while older individuals (7-10-week-old young) are more active and can become infested with ticks outside of the nest (Schneider et al. 1971; Gehrt and Fritzell, 1998).

Piroplasm infections in most species of wildlife are considered to be of low pathogenicity, although under certain circumstances (e.g., coinfections, immunosuppression, stress, climate factors, etc.) they may cause disease (Penzhorn, 2006; Yabsley and Shock, 2012). Examples include babesiosis in African lions suffering from a concurrent canine distemper virus outbreak and decreased food availability, and the development of fatal babesiosis in black rhinoceros due to the stress of capture for translocation efforts (Penzhorn, 2006; Munson et al. 2008). In raccoons, Babesia infections are presumed to be of little clinical significance but most reports are surveys of healthy free-ranging adults. One possible clinical case in a raccoon was a single juvenile raccoon from Illinois that was infected with B. lotori (Birkenheuer et al. 2006). The raccoon was found non-ambulatory with pronounced anaemia, hypoproteinaemia, hypalbuminaemia and elevated alanine aminotransferase with rare intraerythrocytic Babesia parasites. It was treated for Babesia and released; however, it is unknown if it was the Babesia infection that caused the clinical signs or if they were the results of a secondary infection (Birkenheuer et al. 2006). In general, clinical disease is likely to be more pronounced in young animals. Studies on vertical transmission of piroplasms in several hosts indicate that clinical signs in infected young generally occur between 17 and 25 days (Fukumoto et al. 2005; Bednarska et al. 2015; Brown et al. 2015; Adaszek et al. 2016). Because our sampled animals were not available for antemortem testing, we used the ratio of spleen weight:body weight as a measure of possible disease. The association with splenomegaly and Babesia sensu stricto infections, but not with $B$. microti-like sp. infections, suggests that early infections with $B$. lotori or the possible novel Babesia sp. may cause clinical disease in young raccoons. Unfortunately, because these raccoons were dead on arrival or euthanized on entry, no clinical pathology data were collected nor was any histologic analysis done to determine the cause of death or illness (although many were admitted because they were orphaned, not because they were sick). Splenomegaly is one of many common findings of clinical babesiosis in many host species (Kawabuchi et al. 2005; Mierzejewska et al. 2014; Solano-Gallego et al. 2016), including puppies that acquired B. canis infection through vertical transmission (Mierzejewska et al. 2014). Babesia has been detected in raccoons with splenomegaly in Japan; however, only raccoons with splenomegaly were tested and the prevalence of Babesia was low, possibly because raccoons were introduced to Japan (Kawabuchi et al. 2005; Jinnai et al. 2009). It is possible that Babesia spp. of certain wildlife may be more pathogenic than currently recognized but only impact very young animals that are rarely studied.

Because we obtained $B$. microti sequences with the cox1 PCR, this protocol can amplify both Babesia sensu stricto species and $B$. microti-like sp. Unfortunately, due to financial constraints, cloning of these coinfected samples was not possible for this study. However, there were no polymorphic bases present in the coxl sequences although the sequences that failed may have been due to mixed amplicons. We did not PCR test ticks collected from raccoons for piroplasms because ticks were all potentially blood-fed so any positives could have occurred from ingestion of infected blood from the raccoon, the previous infection from another raccoon, or vertical transmission of piroplasms within infected ticks. One of our objectives was to investigate the possibility of vertical transmission of piroplasms to raccoons but since we detected ticks at a young age and dams were not available for 
testing, we could not determine if transmission of piroplasms occurred vertically or via tick transmission.

In summary, we show that several species of Babesia infect very young raccoons. In addition, we showed that several species of ticks are parasitizing these young raccoons, so it is currently unknown if these infections are a result of vertical transmission or tick-transmission due to early infestation. Finally, we note that young raccoons infected with Babesia sensu stricto spp. have a higher spleen:body weight ratio suggesting possible clinical disease associated with infection. Additional studies are needed to better understand the natural history, diversity and impact of Babesia infections in raccoons.

Acknowledgements. We thank Chris Cleveland, Brianna Williams and Maddy Pfaff for assistance with laboratory procedures and statistical analyses. We also thank the staff at both wildlife rehabilitation centres for their assistance with the project.

\section{Financial support}

Financial assistance was provided by the Warnell School of Forestry and Natural Resources (support of K.B.G.) and the sponsorship of the Southeastern Cooperative Wildlife Disease Study by the fish and wildlife agencies of Alabama, Arkansas, Florida, Georgia, Kentucky, Kansas, Louisiana, Maryland, Mississippi, Missouri, Nebraska, North Carolina, Ohio, Oklahoma, Pennsylvania, South Carolina, Tennessee, Virginia and West Virginia, USA. Support from the states to SCWDS was provided in part by the Federal Aid to Wildlife Restoration Act (50 Stat. 917).

\section{Conflict of interest}

None.

\section{Ethical standards}

The authors assert that all procedures contributing to this work comply with the ethical standards of the relevant national and institutional guides on the care and use of laboratory animals. Although no animals were euthanized for the purposes of this study, the collection of biological samples for pathogen testing was reviewed and approved by UGA's Institutional Animal Care and Use Committee (A2014 10-018).

\section{References}

Adaszek L, Obara-Galek J, Piech T, Winiarchzyk M, Kalinowski M and Winiarczyk S (2016) Possible vertical transmission of Babesia canis canis from a bitch to her puppies: a case report. Veterinarni Medicina 61, 263-266. Anderson JF, Magnarelli LA and Sulze AJ (1981) Raccoon babesiosis in connecticut, USA - Babesia lotori sp. n. Journal of Parasitology 67, 417-425.

Bednarska M, Bajer A, Drozdowska A, Mierzejewska EJ, Tolkacz K and Welc-Faleciak (2015) Vertical transmission of Babesia microti in BALB/c mice: preliminary report. PLoS ONE 10, e0137731.

Birkenheuer AJ, Levy MG and Breitschwerdt EB (2003) Development and evaluation of a seminested PCR for detection and differentiation of Babesia gibsoni (Asian genotype) and B. canis DNA in canine blood samples. Journal of Clinical Microbiology 41, 4172-4177.

Birkenheuer AJ, Whittington J, Neel J, Large E, Barger A, Levy MG and Breitschwerdt EB (2006) Molecular characterization of a Babesia species identified in a North American raccoon. Journal of Wildlife Diseases 42, 375-380.

Birkenheuer AJ, Marr HS, Hladio N and Acton AE (2007) Molecular evidence of prevalent dual piroplasma infections in North American raccoons (Procyon lotor). Parasitology 135, 33-37.

Bishopp FC and Trembley HL (1945) Distribution and hosts of certain North American ticks. The Journal of Parasitology 31, 1-54.
Brown AL, Shiel RE and Irwin PJ (2015) Clinical, haematological, cytokine and acute phase protein changes during experimental Babesia gibsoni infection of beagle puppies. Experimental Parasitology 157, 185-196.

Clark K, Savick K and Butler J (2012) Babesia microti in rodents and raccoons from northeast Florida. Journal of Parasitology 98, 1117-1121.

Costa SCL, de Magalhães VCS, de Oliveira UV, Carvalho FS, de Almeida CP, Machado RZ and Munhoz AD (2016) Transplacental transmission of bovine tick-borne pathogens: frequency, co-infections and fatal neonatal anaplasmosis in a region of enzootic stability in the northeast of Brazil. Ticks and Tick-borne Diseases 7, 270-275.

Dharmarajan G, Beasley JC, Beatty WS, Olson ZH, Fike JA and Rhodes Jr OE (2016) Genetic co-structuring in host-parasite systems: empirical data from raccoons and raccoon ticks. Exosphere 7, 1-15.

Dennis JR, Durden LA and Snyder DE (1994) Ectoparasites of the raccoon (Procyon lotor) from North-Central Arkansas. Journal of the Kansas Entomological Society 67, 208-212.

Durden LA and Keirans JE (1996) Nymphs of the Genus Ixodes (Acari: Ixodidae) of the United States: Taxonomy, Identification Key, Distribution, Hosts, and Medical/Veterinary Importance. Entomological Society of America, Lanham, Maryland.

Durden LA, Beckmen KB and Gerlach RF (2016) New records of ticks (Acari: Ixodidae) from dogs, cats, humans, and some wild vertebrates in Alaska: invasion potential. Journal of Medical Entomology 53, 1391-1395.

Fukumoto S, Suzuki H, Igarashi I and Xuan X (2005) Fatal experimental transplacental Babesia gibsoni infections in dogs. International Journal for Parasitology 35, 1031-1035.

Gabriel MW, Brown RN, Foley JE, Higley JM and Botzler RG (2009) Ecology of Anaplasma phagocytophilum infection in gray foxes (Urocyon cinereoargenteus) in northwestern California. Journal of Wildlife Diseases 45, 344-354.

Gehrt SD and Fritzell EK (1998) Duration of familial bonds and dispersal patterns for raccoons in South Texas. Journal of Mammology 79, 859872.

Gleim ER, Conner LM, Berghaus RD, Levin ML, Zemtsova GE and Yabsley MJ (2014) The phenology of ticks and the effects of long-term prescribed burning on tick population dynamics in southwestern Georgia and northwestern Florida. PLOS ONE 9, e112174.

Goethert HK and Telford III SR (2003) What is Babesia microti? Parasitology 127, 301-309.

Guglielmone AA, Robbins RG, Apanaskevich DA, Petney TN, Estrada-Peña A and Horak IG (2014) The Hard Ticks of the World (Acari: Ixodida: Ixodidae). Dordrecht: Springer.

Hersh MH, Tibbetts M, Strauss M, Ostfeld RS and Keesing F (2012) Reservoir competence of wildlife host species for Babesia microti. Emerging Infectious Diseases 18, 1951-1957.

Hunfeld KP, Hildebrant A and Gray JS (2008) Babesiosis: recent insights into an ancient disease. International Journal for Parasitology 38, 1219-1237.

Jinnai M, Kawabuchi-Kurata T, Tsuji M, Nakajima R, Fujisawa K, Nagata S, Koide H, Matoba Y, Asakawa M, Takahashi K and Ishihara C (2009) Molecular evidence for the presence of new babesia species in feral raccoons (Procyon lotor) in Hokkaido, Japan. Veterinary Parasitology 162, 241-247.

Joseph JT, Purtill K, Wong SJ, Munoz J, Teal A, Madison-Antenucci S, Horowitz HW, Aguero-Rosenfeld ME, Moore JM, Abramowsky C and Wormser GP (2012) Vertical transmission of Babesia microti, United States. Emerging Infectious Diseases 18, 1318-1321.

Kawabuchi T, Tsuji M, Sado A, Matoba Y, Asakawa M and Ishihara C (2005) Babesia microti-like parasites detected in feral raccoons (Procyon lotor) captured in Hokkaido, Japan. Journal of Veterinary Medicine 67, 825-827.

Keirans JE and Litwak TR (1989) Pictorial key to the adults of hard ticks, family Ixodidae (Ixodida: Ixodoidea), east of the Mississippi River. Journal of Medical Entomology 26, 435-446.

Lack JB, Reichard MV and Van Den Bussche RA (2012) Phylogeny and evolution of the Piroplasmida as inferred from 18S rRNA sequences. International Journal for Parasitology 42, 353-363.

Li LH, Zhu D, Zhang CC, Zhang Y and Zhou XN (2016) Experimental transmission of Babesia microti by Rhipicephalus haemaphysaloides. Parasites \& Vectors 9, 231.

Mierzejewska EJ, Welc-Faleciak R, Bednarska M, Rodo A and Bajer A (2014) The first evidence for vertical transmission of Babesia canis in a litter of central Asian shepherd dogs. Annals of Agricultural and Environmental Medicine 21, 500-503. 
Montgomery GG (1964) Tooth eruption in preweaned raccoons. Journal of Wildlife Management 28, 582-584.

Munson L, Terio KA, Kock R, Mlengeya T, Roelke ME, Dubovi E, Summers B, Sinclair ARE and Packer C (2008) Climate extremes promote fatal co-infections during canine distemper epidemics in African lions. PLoS ONE. 3(6). doi: 10.1371/journal.pone.0002545.

Ouellette J, Apperson CS, Howard P, Evans TL and Levine JF (1997) Tick-raccoon associations and the potential for lyme disease spirochete transmission in the coastal plain of North Carolina. Journal of Wildlife Diseases 33, 28-39.

Paraense WL (1949) Paraense: canine babesiasis. Memórias do Instituto Oswaldo Cruz 47, 375-380.

Penzhorn BL (2006) Babesiosis of wild carnivores and ungulates. Veterinary Parasitology 138, 11-21.

Qurollo BA, Archer NR, Schreeg ME, Marr HS, Birkenheuer AJ, Haney KN, Thomas BS and Breitschwerdt EB (2017) Improved molecular detection of Babesia infections in animals using a novel quantitative real-time PCR diagnostic assay targeting mitochondrial DNA. Parasites and Vectors 10, 128 doi: 10.1186/s13071-017-2064-1.

Ruebush Jr TK, Piesman J, Collins WE, Spielman A and Warren M (1981) Tick transmission of Babesia microti to rhesus monkey (Macaca mulatta). American Journal of Tropical Medicine and Hygiene 30, 555-559.

Schaffer GD, Hanson WL, Davidson WR and Nettles VF (1978) Hematotropic parasites of translocated raccoons in the southeast. Journal of the American Veterinary Medical Association 173, 1148-1151.

Schneider DG, Mech LD and Tester JR (1971) Movements of female raccoons and their young as determined by radio tracking. Animal Behaviour Monographs 4, 1-43.

Schreeg ME, Marr HS, Tarigo JL, Cohn LA, Bird DM, Scholl EH, Levy MG, Weigmann BM and Birkenheuer AJ (2016) Mitochondrial genome sequences and structures aid in the resolution of Piroplasmida phylogeny. PLoS ONE. 11(11). doi: 10.1371/journal.pone.0165702.
Solano-Gallego L, Sainz À, Roura X, Estrada-Peña A and Miró G (2016) A review of canine babesiosis: the European perspective. Parasites and Vectors 9, 336. doi: 10.1186/s13071-016-1596-0.

Sonenshine DE (1993) Biology of Ticks, Vol. 2. Oxford University Press, New York, New York, USA.

Telford Jr SR and Forrester DJ (1991) Hemoparasites of raccoons (Procyon lotor) in Florida. Journal of Wildlife Diseases 27, 486-490.

Tolkacz K, Bednarska M, Alsarraf M, Dquznik D, Grzybek M, Welc-Faleciak R, Behnke JM and Bajer A (2017) Prevalence, genetic identity and vertical transmission of Babesia microti in three naturally infected species of vole, Microtus spp. (Cricetidae). Parasites and Vectors 10, 66. doi: 10.1186/s13071-017-2007-x.

Uilenberg G (2006) Babesia-A historical overview. Veterinary Parasitology 138, 3-10.

Yabsley MJ and Shock BC (2012) Natural history of zoonotic Babesia: role of wildlife reservoirs. International Journal of Parasitolgy: Parasites and Wildlife 2, 18-31.

Yabsley MJ, Murphy SM, Luttrell MP, Little SE, Massung RF, Stallknecht DE, Conti LA, Blackmore CG and Durden LA (2008) Experimental and field studies on the suitability of raccoons (Procyon lotor) as hosts for tick-borne pathogens. Vector Borne and Zoonotic Diseases 8, 491-503.

Yeagley TJ, Reichard MV, Hempstead JE, Allen KE, Parsons LM, White MA, Little SE and Meinkoth JH (2009) Detection of Babesia gibsoni and the canine small Babesia 'Spanish isolate' in blood samples obtained from dogs confiscated from dogfighting operations. Journal of the American Veterinary Medical Association 235, 535-539.

Yeruham I, Avidar Y, Aroch I and Hadani A (2003) Intra-uterine infection with Babesia bovis in a 2-day-old calf. Journal of Veterinary Medicine 50, $60-62$.

Yin H, Lu W, Luo J, Zhang Q, Lu W and Dou H (1996) Experiments on the transmission of Babesia major and Babesia bigemina by Haemaphysalis punctata. Veterinary Parasitology 67, 89-98. 